\title{
Analisis statik kekuatan struktur pesawat UAV vertical take off-landing VX-2
}

\author{
Djarot Wahju Santoso*, Wawan Edi Saputra \\ Program Studi Teknik Dirgantara Sekolah Tinggi Teknologi Adisutjipto \\ Email Korespondensi: *djarot_wahyu84@yahoo.com
}

\begin{abstract}
VTOL UAV aircraft is aircraft capable of vertical takeoff and landing (VTOL) and have flexible maneuverability. This aircraft is increasingly being used because of its ability to carry out various missions. The aircraft modification process that was previously designed for the VTOL VX-1 was carried out to correct problems encountered during flight tests. The stages of research carried out in the static analysis of the structural strength of the UAV VX-2 aircraft were to modify the wing structure, fuselage and tail of the previous aircraft design, carry out modeling with CATIA software and then analyze the structure with Patran-Nastran to ensure the modification was safe. The result of the analysis the modified structure of the UAVVX-2 aircraft design, the wing structure has a maximum stress $185 \mathrm{MPa}$ in the case of torsion loads, while the maximum tension tail structure $257 \mathrm{MPa}$ is located in the horizontal stringer stabilizer at pull up loads. The results of the calculation the Margin of Safety with all positive values, the modified structure is declared safe.
\end{abstract}

Keywords: Static analysis, UAV VTOL VX-2, structural strength.

\section{Pendahuluan}

Pesawat Terbang Tanpa Awak (PTTA) sering disebut Unmanned Aerial Vehicle (UAV) merupakan pesawat udara yang mampu terbang dengan interval waktu tertentu tanpa dikendarai oleh pilot, pengendalian pesawat dilakukan secara otomatis melalui perangkat elektronik yang diprogram serta mampu melakukan misinya berulang kali. Penggunaan pesawat UAV diantaranya untuk penginderaan jarak jauh, penghubung alat komunikasi, serta pemantauan kondisi bencana alam. UAV biasanya dilengkapi peralatan kamera guna merekam suatu objek yang dapat dijadikan data untuk kegiatan pemetaan suatu wilayah dengan salah satu sistem yaitu Sistem Informasi Geogafis [1].

Saat ini pengembangan pesawat UAV telah banyak dilakukan baik yang mempunyai konfigurasi fixed wing maupun yang menggunakan model rotary wing yang memiliki multi rotor. Pemilihan konfigurasi tersebut biasanya tergantung dari misi yang akan diemban pesawat. Konfigurasi berikutnya adalah yang memanfaatkan masing-masing kelebihan dari 2 konfigurasi sebelumnya yaitu pesawat yang merupakan fixed wing yang dilengkapi dengan multi rotor. Pesawat ini mampu melakukan lepas landas (take-off) dan pendaratan secara vertikal (VTOL) serta kemampuan manuvernya yang fleksibel sehingga tidak memerlukan landasan yang panjang.

Kajian pengembangan pesawat UAV kebanyakan menggunakan konfigurasi rotary wing yang 
mempunyai 4 rotor (quadcopter). Pranay dkk, [2] menggunakan Glass Fibre Reinforced Plastic (GFRC) sebagai bahan framenya untuk misi mengangkut darah dan obat-obatan darurat, menyusul pengembangan berikutnya menggunakan konfigurasi fixed wing [3].

Patra dkk., 2017 [4] melakukan pengembangan pesawat VTOL fixed wing yang mempunyai 3 rotor dapat diputar pada sudut $90^{\circ}$ sehingga mampu terbang vertikal maupun terbang cruise. Rancangan pesawat tersebut mampu membawa muatan $1 \mathrm{~kg}$, dengan jarak tempuh $1 \mathrm{~km}$ serta endurance terbang stabil selama 16 menit.

Rancangan berikutnya menggunakan 4 rotor dilakukan Sandilya, B dkk, 2014 [5]. Rancangan ini mampu terbang vertikal dan landing karena menggunakan rotor yang dapat berputar $90^{\circ}$. Berat total pesawat tersebut $5 \mathrm{~kg}$, dengan geometri wing span 1,5 m dan mampu terbang dengan kecepatan $25 \mathrm{~m} / \mathrm{s}$. Generasi UAV dengan konfigurasi VTOL berikutnya [6-8], sedangkan UAV yang mampu membawa muatan $8 \mathrm{~kg}$ selama 3 jam dengan radius operasionalnya $35 \mathrm{~km}$ memiliki berat MTOW $45 \mathrm{~kg}$ [9].

Pesawat VTOL VX-2 merupakan pengembangan pesawat VTOL VX-1 [10] yang mempunyai misi untuk melakukan pemantauan kondisi kepadatan lalu lintas di suatu kota. Pesawat ini merupakan modifikasi dari pesawat VTOL VX-1 yang memiliki beberapa kendala saat dilakukan uji fungsi terbang. Adapun kendala yang dijumpai diantaranya ruangan untuk menempatkan sistem di bagian fuselage yang terlalu sempit, serta rancangan sayap yang tidak fleksibel saat diassembli, serta sambungan sayap dengan fuselage yang belum begitu kuat saat dilakukan uji terbang.

Fokus penelitian ini adalah melakukan modifikasi pesawat UAV VTOL VX-1 dengan melakukan perubahan goemetri pada fuselage, penambahan stringer pada sayap, memperbaiki sistem assembli pada sayap dan tail. Langkah selanjutnya adalah melakukan analisis statik kekuatan struktur pesawat yang sudah dimodifikasi menggunakan software Pastran Nastran untuk memastikan struktur pesawat tersebut aman.

\section{Metodologi Penelitian}

Tahapan penelitian yang dilakukan dapat dijelaskan sebagai berikut:

1. Studi Literatur

Pada tahap ini menggali sumber referensi yang berhubungan dengan topik penelitian seperti buku, jurnal, serta sumber referensi yang lain.

2. Proses Modifikasi Rancangan

Pada tahap ini dilakukan proses modifikasi geometri pesawat UAV VX-1 untuk memperbaiki kendala yang yang terjadi sebelumnya serta memperbaiki konsep assembly saat proses manufaktur.

3. Analisis Statik Kekuatan Struktur

Tahap ini melakukan pemodelan geometri hasil proses modifikasi dengan software CATIA V5R21. Menentukan pembebanan pada model menggunakan beban maneuver, beban torsi saat kondisi take off, serta beban aerodinamik pada tail. Tahap berikutnya melakukan analisis struktur dengan software MSC Patran Nastran serta menghitung kekuatan struktur berdasarkan nilai Margin of Safety [11]. Untuk memvalidasi model simulasi dilakukan uji konvergensi pada nilai tegangan yang dihasilkan akibat perubahan jumlah elemen.

\subsection{Proses Pemodelan Modifikasi Pesawat UAV VX-2}

\section{Pemodelan Sayap}

Pada pemodelan sayap tidak mengalami perubahan dimensi secara umum, kecuali penguat sayap dan rancangan sambungan antar part. Beberapa permasalahan yang ditemukan saat uji terbang VX-1, sayap belum kuat menahan beban torsi saat melakukan take off. Untuk mempermudah manufaktur maupun handling, rancangan sayap dibagi menjadi 2 bagian dan disambung dengan batang tube karbon. Sambungan sayap dengan batang VTOL menggunakan klem. Gambar 1 menunjukkan pemodelan sayap modifikasi VX-2, sedangkan geometri sayap tercantum pada Tabel 1. 


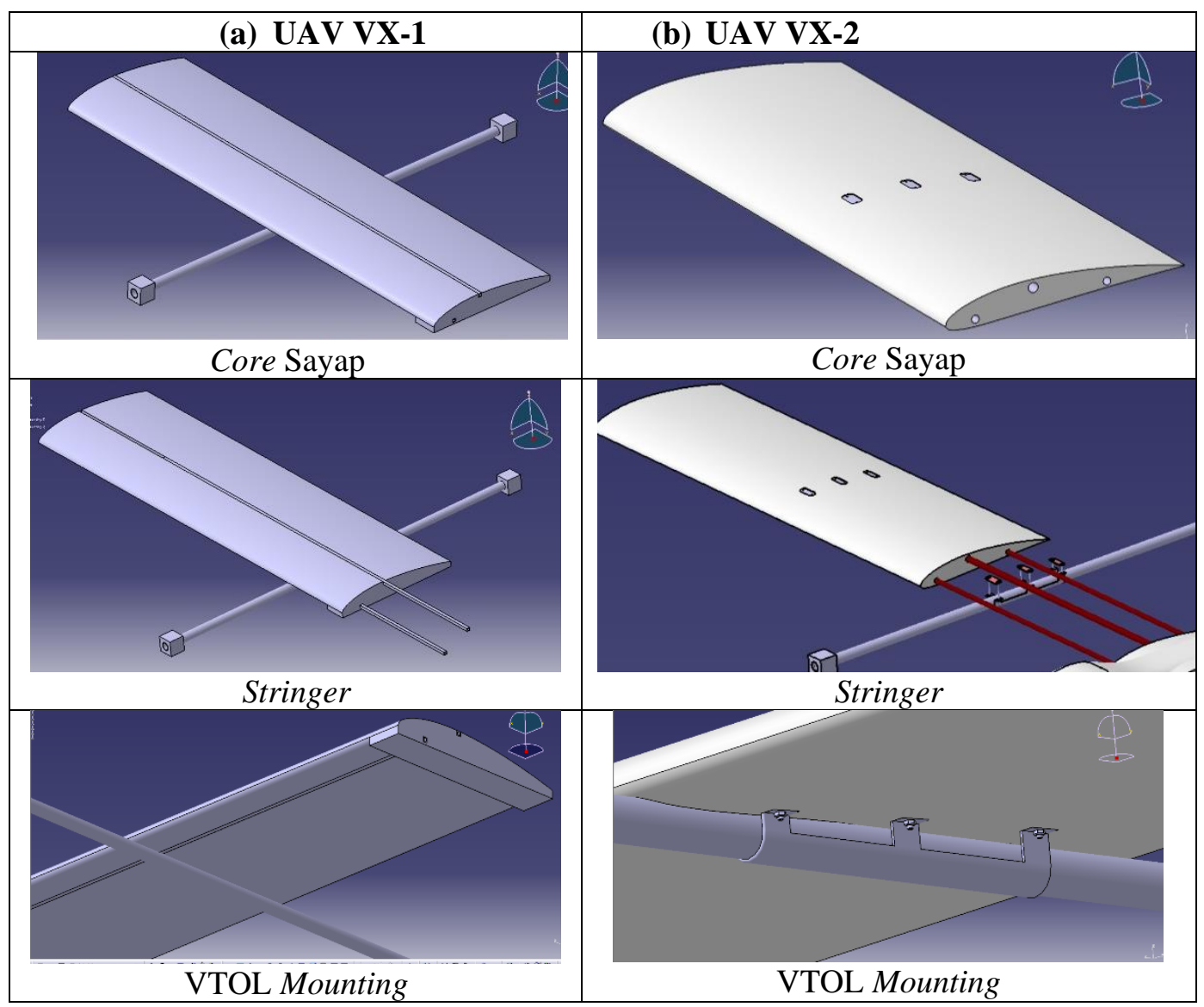

Gambar 1. Model sayap (a) UAV VX-1 (b) UAV VX-2

Tabel 1. Dimensi Sayap UAV VX-1 dan VX-2

\begin{tabular}{clcc}
\hline No. & \multicolumn{1}{c}{ Geometri } & UAV VX-1 & UAV VX-2 \\
\hline 1. & Aspect ratio $(\mathrm{Ar})$ & 7 & 7 \\
2. & Luas sayap $(\mathrm{Sw})$ & $0,419257 \mathrm{~m}^{2}$ & $0,419257 \mathrm{~m}^{2}$ \\
3. & Wing span $(\mathrm{bw})$ & $1,713125 \mathrm{~m}$ & $1,713125 \mathrm{~m}$ \\
4. & Chord wing $(\mathrm{Cw})$ & $0,244732 \mathrm{~m}$ & $0,244732 \mathrm{~m}$ \\
5. & Jumlah stringer & 2 & 3 \\
6. & Dimensi stringer $(\mathrm{mm})$ & Front $(6 / 4) ;$ & Front $(8 / 6) ;$ Mid $(10 / 8,5) ;$ \\
& (Douter $\left./ \mathrm{D}_{\text {inner }}\right)$ & Rear $(6 / 4)$ & Rear $(8 / 6)$ \\
7. & Teknik pemasangan sayap & Fix & Modular \\
8. & Proses pemasangan batang VTOL & - & Clamp mounting 3 titik \\
\hline
\end{tabular}

2. Pemodelan Fuselage

Perubahan desain yang dilakukan pada fuselage adalah penambahan dimensi eksternal dan internal, hal ini untuk mengakomodasi semua peralatan sistem yang dipasang pada pesawat sebelumnya terlalu sempit ruangannya. Perubahan selanjutnya desain wing mounting, posisi kamera, konsep desain lepas pasang (modular), serta bentuk aerodinamika fuselage yang dirancang lebih aerodinamis. Gambar 2 merupakan modifikasi fuselage antara pemodelan UAV VX-1 dengan UAV VX-2 sedangkan dimensinya ditunjukkan pada Tabel 2. 

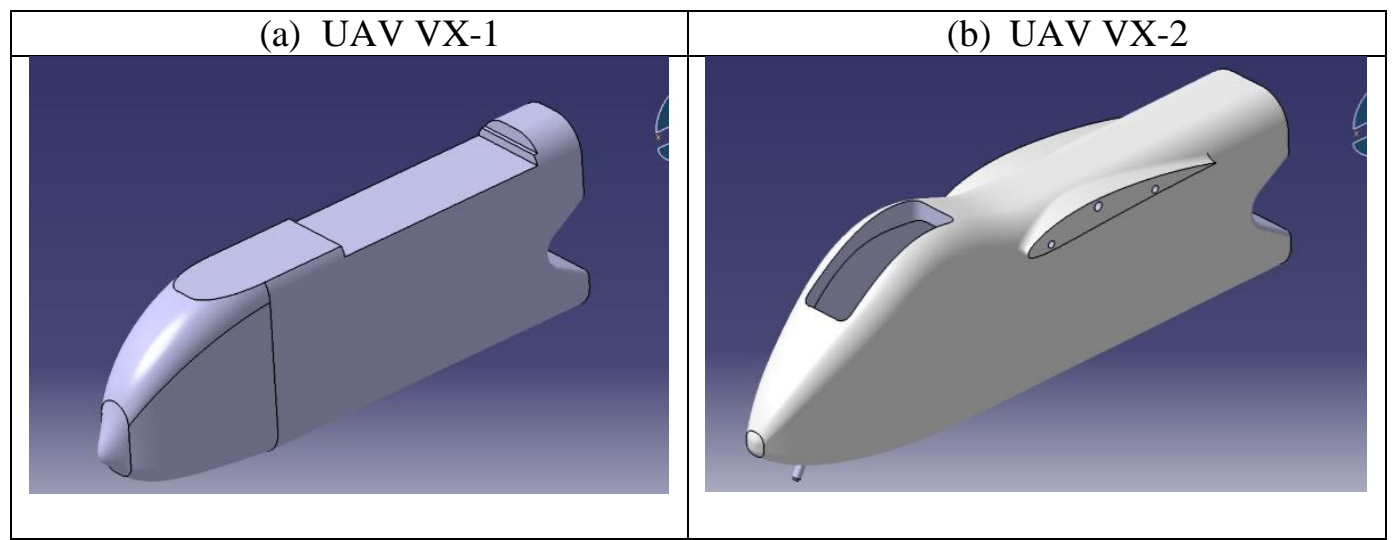

Gambar 2. Model Fuselage (a) UAV VX-1 dan (b) UAV VX-2

Tabel 2. Dimensi Fuselage UAV VX-1 dan VX-2

\begin{tabular}{clcc}
\hline No. & \multicolumn{1}{c}{ Geometri } & UAV VX-1 $(\mathrm{mm})$ & UAV VX-2 $(\mathrm{mm})$ \\
\hline 1. & Panjang nose-tail & 1321 & 1321 \\
2. & Panjang fuselage & 580 & 650 \\
3. & Tinggi fuselage & 190 & $190-218$ \\
4. & Lebar fuselage & 95 & 110 \\
5. & Panjang internal fuselage & 390 & 455 \\
6. & Tinggi internal fuselage & 125 & 145 \\
7. & Lebar internal fuselage & 60 & 80 \\
8. & Wing Mounting & Fix & Modular \\
\hline
\end{tabular}

3. Pemodelan Tail

Pada rancangan tail VX-1 posisi penempatan elevator serta posisi stringer belum dilakukan, sehingga hasil analisis aerodinamika dan struktur belum akurat. Gambar 2 menunjukkan pemodelan tail UAV VX1 dan VX-2. Penentukan letak stringer dilakukan pada posisi bagian yang mengalami tegangan yang tinggi saat simulasi. Untuk memudahkan proses assembli, konsep lepas pasang (modular) diterapkan dalam membuat model part horizontal stabilizer. Dimensi kedua model UAV dapat dilihat pada Tabel 3.

\begin{tabular}{|l|l|}
\hline (a) UAV VX-1 & (b) UAV VX-2 \\
\hline & \\
\hline
\end{tabular}




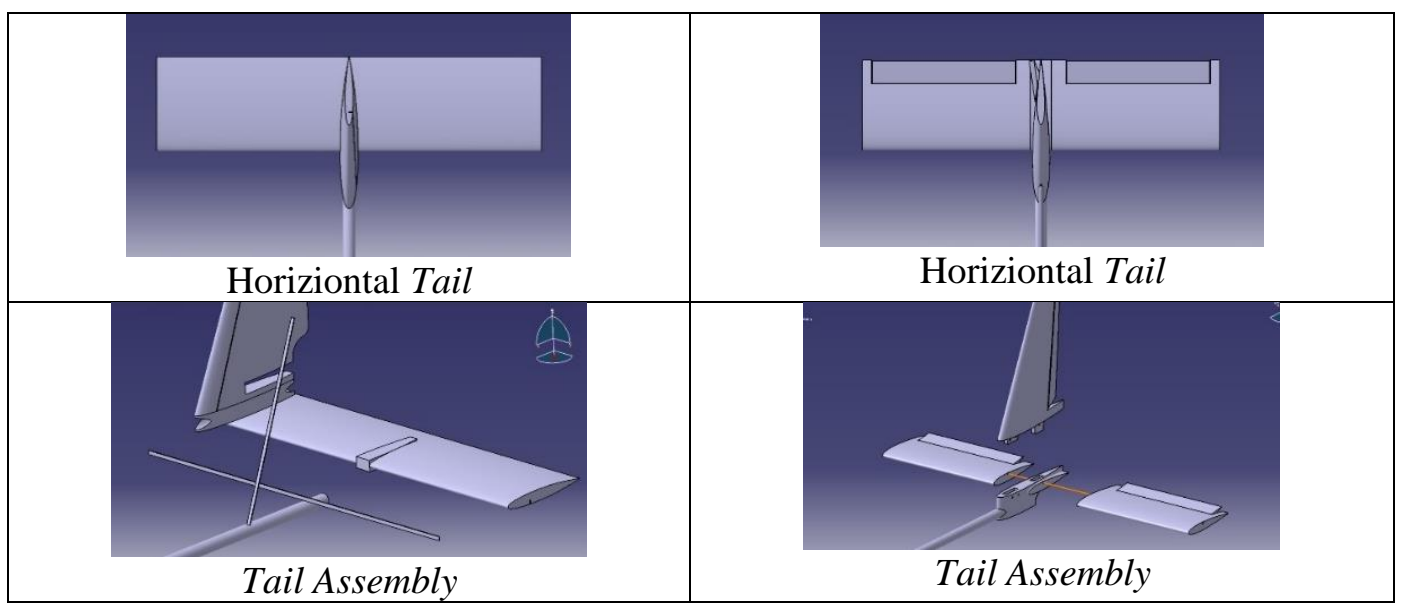

Gambar 3. Model Tail (a) UAV VX-1 dan (b) UAV VX-2

Tabel 3. Dimensi Tail UAV VX-1 dan VX-2

\begin{tabular}{|c|c|c|c|}
\hline No. & Geometri & UAV VX-1 & UAV VX-2 \\
\hline 1. & Vertical tail area $(\mathrm{Svt})$ & $0,033258 \mathrm{~m}^{2}$ & $0,033258 \mathrm{~m}^{2}$ \\
\hline 2. & Vertical tail span (bvt) & $0,234254 \mathrm{~m}$ & $0,234254 \mathrm{~m}$ \\
\hline \multirow[t]{2}{*}{4.} & Chord vertical tail & $0,195824 \mathrm{~m}($ root $)$ & $0,195824 \mathrm{~m}$ (root) \\
\hline & & $0,088121 \mathrm{~m}($ tip $)$ & $0,088121 \mathrm{~m}(\mathrm{tip})$ \\
\hline 4. & Horizontal tail area (Sht) & $0,059389 \mathrm{~m}^{2}$ & $0,059389 \mathrm{~m}^{2}$ \\
\hline 5. & Horizontal tail span (bht) & $0,487395 \mathrm{~m}$ & $0,487395 \mathrm{~m}$ \\
\hline 6. & Chord horizontal tail (Cht) & $0,121849 \mathrm{~m}$ & $0,121849 \mathrm{~m}$ \\
\hline 7. & Aileron span (b aileron) & $0,770906 \mathrm{~m}$ & $0,770906 \mathrm{~m}$ \\
\hline 8. & Aileron chord (C aileron) & $0,041604 \mathrm{~m}$ & $0,041604 \mathrm{~m}$ \\
\hline 9. & Rudder span (b rudder) & $0,210829 \mathrm{~m}$ & $0,210829 \mathrm{~m}$ \\
\hline \multirow[t]{2}{*}{10.} & Rudder chord (C rudder) & $0,058747 \mathrm{~m}$ (root) & 0,058747 m (tip) \\
\hline & & 0,035248 m (tip) & 0,035248 m (tip) \\
\hline 11. & Elevator span (b elevator) & $0,389916 \mathrm{~m}$ & $0,389916 \mathrm{~m}$ \\
\hline 12. & Elevator chord (C elevator) & $0,030462 \mathrm{~m}$ & $0,030462 \mathrm{~m}$ \\
\hline 13. & Airfoil tail & 0012 & 0012 \\
\hline 14. & Jumlah stringer & 2 & 1 \\
\hline 15. & Dimensi stringer $(\mathrm{mm})$ & $\begin{array}{l}\text { Rectangular section } \\
\qquad(\mathrm{l}=5 ; \mathrm{t}=1)\end{array}$ & $\begin{array}{c}\text { Tube } \\
\left(\mathrm{D}_{\text {outter }}=3 ; \mathrm{D}_{\text {inner }}=2\right)\end{array}$ \\
\hline
\end{tabular}

Berikut adalah hasil akhir proses modifikasi pesawat VX-2 seperti terlihat pada Gambar 4.

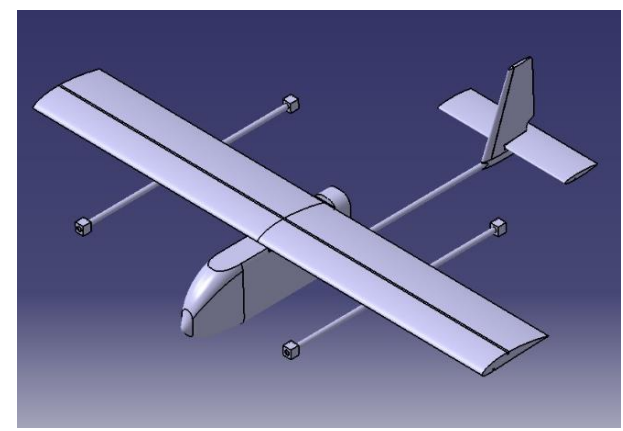

(a)

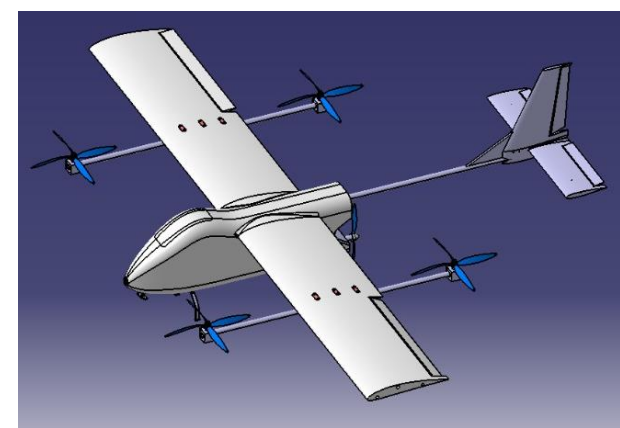

(b)

Gambar 4. Model pesawat (a) UAV VX-1 dan (b) UAV VX-2 


\subsection{Pembebanan}

Kasus pembebanan yang diterapkan pada model sayap, fuselage, dan tail UAV VX-2 merupakan beban limit. Beban ini terdiri dari 3 kasus pembebanan yaitu manuver (pull up), beban torsi, dan beban aerodinamik pada tail. Beban limit pada sayap dan fuselage diperoleh dari gaya angkat pesawat dikalikan dengan load factor. Berat pesawat menggunakan Maximum Take Off Weight (MTOW) sedangkan load factor mengacu pada standar regulasi pesawat UAV Australia C.A.S.A. Australia Subpart C - Structure UA25.337 [4]. Berikut adalah perhitungan berat MTOW pesawat UAV VX-2.

$$
\mathrm{W}=\mathrm{m} . \mathrm{g}=2,865357 \mathrm{~kg} \times 9,81 \mathrm{~m} / \mathrm{s}^{2}=28,109 \mathrm{~N}
$$

1. Kondisi Terbang Manuver (Pull Up)

Pada kondisi ini pesawat diasumsikan terbang pada kondisi manuver yaitu pull up. Pembebanan limit diterapkan pada kondisi ini dengan asumsi load factor sebesar 3,8 dikalikan berat MTOW UAV VX-2.

$\mathrm{L}_{\text {manuver }}=\mathrm{n} . \mathrm{W}=3,8 \times 28,109 \mathrm{~N}=106,815 \mathrm{~N}$

Beban tersebut diterapkan pada core sayap UAV VX-2. Analisis pembebanan manuver dilakukan pada setengah span sayap.

$$
\mathrm{L}_{\text {manuver }}=106,815 / 2=53,407 \mathrm{~N}
$$

\section{Kondisi Beban Torsi}

Pada kondisi beban torsi, sayap diasumsikan mengalami pembebanan momen pada suatu titik di salah satu engine mounting belakang. Kondisi ini terjadi saat pesawat melakukan transisi dari vertical take off ke cruising. Diasumsikan bebannya merupakan beban saat take off dikalikan load factor 3,8, hasil ini dikalikan panjang batang VTOL $310 \mathrm{~mm}$ untuk memperoleh besar momen torsi. Beban take off pada satu engine mounting sama dengan beban total dibagi 4 yang merupakan jumlah motor pada pesawat.

$$
\mathrm{M} \quad=\mathrm{F} \times 1=26,704 \mathrm{~N} \times 310 \mathrm{~mm}=8.278,163 \mathrm{Nmm}
$$

3. Kondisi Beban Aerodinamik Tail

Pembebanan pada tail diperoleh dengan mensimulasi aliran udara yang dikenakan di bagian tail pada saat rudder maupun elevator didefleksikan pada sudut $15^{\circ}$. Hasil gaya pada arah $\mathrm{X}, \mathrm{Y}$ dan $\mathrm{Z}$ diambil sebagai input simulasi struktur di MSC Patran-Nastran. Kecepatan aliran udara dalam simulasi aerodinamik tail adalah sebesar 40,5 m/s [13]. Besarnya kasus pembebanan diterapkan pada model UAV VX-2 tercantum pada Tabel 4.

Tabel 4. Kasus Pembebanan Sayap dan Fuselage

\begin{tabular}{llcccccc}
\hline No. & $\begin{array}{c}\text { Kasus } \\
\text { Pembebanan }\end{array}$ & Fx & Fy & Fz & Mx & My & Mz \\
\cline { 2 - 7 } & Pull Up & 0 & 0 & 53,407 & 0 & 0 & 0 \\
\hline 1. & Punsi & $(\mathrm{N})$ & 0 & $0.278,163$ & 0 \\
2. & Torsi & 0 & 0 & 0 & 0 & 0 & 0 \\
3. & Fuselage & 0 & 0 & $-106,82$ & 0 & 0 & 0 \\
4 & Horizontal Tail & $-1,3485$ & $-0,2034$ & $-13,834$ & 0 & 0 & 0 \\
5 & Vertical Tail & $-1,923$ & 18,336 & 0,365 & 0 & 0 & 0 \\
\hline
\end{tabular}

2.3 Pemilihan material

Berdasarkan kebutuhan persyaratan pesawat VX-2 yang harus ringan dengan batasan berat take off-nya serta menyesuaikan ketersediaan material di lapangan, maka ditentukan beberapa material berikut.

Tabel 5. Mechanical Properties Material Styrofoam

(Sumber : www.matweb.com [14])

\begin{tabular}{ccc}
\hline Karakteristik & Nilai & Satuan \\
\hline Modulus Elastisitas & 20,3 & $\mathrm{MPa}$ \\
Poisson's Ratio & 0,3 & - \\
Shear Modulus & 1230 & $\mathrm{MPa}$ \\
Massa Jenis & 3,1 & $\mathrm{Kg} / \mathrm{m}^{3}$ \\
Yield Strength & 0,641 & $\mathrm{MPa}$ \\
\hline
\end{tabular}


Tabel 6. Mechanical Properties Material Carbon (Sumber : www.matweb.com [14])

\begin{tabular}{ccc}
\hline Karakteristik & Nilai & Satuan \\
\hline Modulus Elastisitas & 84000 & $\mathrm{MPa}$ \\
Poisson's Ratio & 0,1 & - \\
Shear Modulus & 4300 & $\mathrm{MPa}$ \\
Massa Jenis & 1490 & $\mathrm{Kg} / \mathrm{m}^{3}$ \\
Yield Strength & 867 & $\mathrm{MPa}$
\end{tabular}

\subsection{Uji Konvergensi}

Untuk memvalidasi hasil simulasi pemodelan dilakukan uji konvergensi untuk melihat tren tegangan yang dihasilkan akibat perubahan jumlah elemen. Tegangan yang dipilih adalah nilai tegangan dengan rentang perbedaan dikisaran $2 \%$ dimana nilai tegangan tersebut sudah menunjukkan kecenderungan kearah nilai stabil. Uji konvergensi dilakukan dengan melakukan perubahan variasi jumlah mesh yang akan menghasilkan perbedaan jumlah elemennya. Proses konvergensi dilakukan satu per satu pada struktur sayap, fuselage, vertical tail, dan horizontal tail. Hasil proses konvergensi dicantumkan pada Tabel 7, 8, 9 dan 10.

Untuk struktur sayap jumlah elemen di atas 3000 sudah menunjukkan nilai tegangan yang stabil, sedangkan struktur fuselage membutuhkan elemen di atas 4500 , vertical tail membutuhkan minimal 12000 elemen serta 1000 elemen lebih dibutuhkan untuk struktur horizontal tail supaya nilai tegangan stabil.

Tabel 7. Nilai Uji Konvergensi Sayap

\begin{tabular}{ccc}
\hline No. & Jumlah Elemen & Tegangan $(\mathrm{MPa})$ \\
\hline 1. & 186 & 0.561 \\
2. & 372 & 1 \\
3. & 744 & 1.02 \\
4. & 1488 & 1.13 \\
5. & 5904 & 1.15 \\
6. & 11808 & 1.21 \\
\hline
\end{tabular}

Tabel 8. Nilai Uji Konvergensi Fuselage

\begin{tabular}{ccc}
\hline No. & Jumlah Elemen & Tegangan (MPa) \\
\hline 1. & 3915 & 0.297 \\
2. & 4282 & 0.363 \\
3. & 4518 & 0.387 \\
4. & 5316 & 0.395 \\
\hline
\end{tabular}

Tabel 9. Nilai Uji Konvergensi Vertical Tail

\begin{tabular}{ccc}
\hline No. & Jumlah Elemen & Tegangan (MPa) \\
\hline 1. & 100 & 0.184 \\
2. & 200 & 0.205 \\
3. & 1552 & 0.225 \\
4. & 12320 & 0.242 \\
5. & 24640 & 0.246 \\
\hline
\end{tabular}


Tabel 10. Nilai Uji Konvergensi Horizontal Tail

\begin{tabular}{ccc}
\hline No. & Jumlah Elemen & Tegangan $(\mathrm{MPa})$ \\
\hline 1. & 50 & 0.437 \\
2. & 100 & 0.546 \\
3. & 200 & 0.624 \\
4. & 400 & 0.676 \\
5. & 6160 & 0.679 \\
6. & 98320 & 0.694 \\
\hline
\end{tabular}

\section{Hasil dan Pembahasan}

3.1. Analisis struktur sayap pada beban maneuver (pull up)

Pada kasus ini beban sebesar 53,407 $\mathrm{N}$ dikenakan pada core sayap sedangkan tumpuan (clamp) diletakkan pada posisi root sayap. Tegangan maksimum sebesar 0,233 MPa terjadi pada core bagian root yaitu node 13210, hal ini terjadi karena momen terbesar ada di bagian root sayap sehingga tegangan bending maksimum akan terjadi di bagian tersebut.

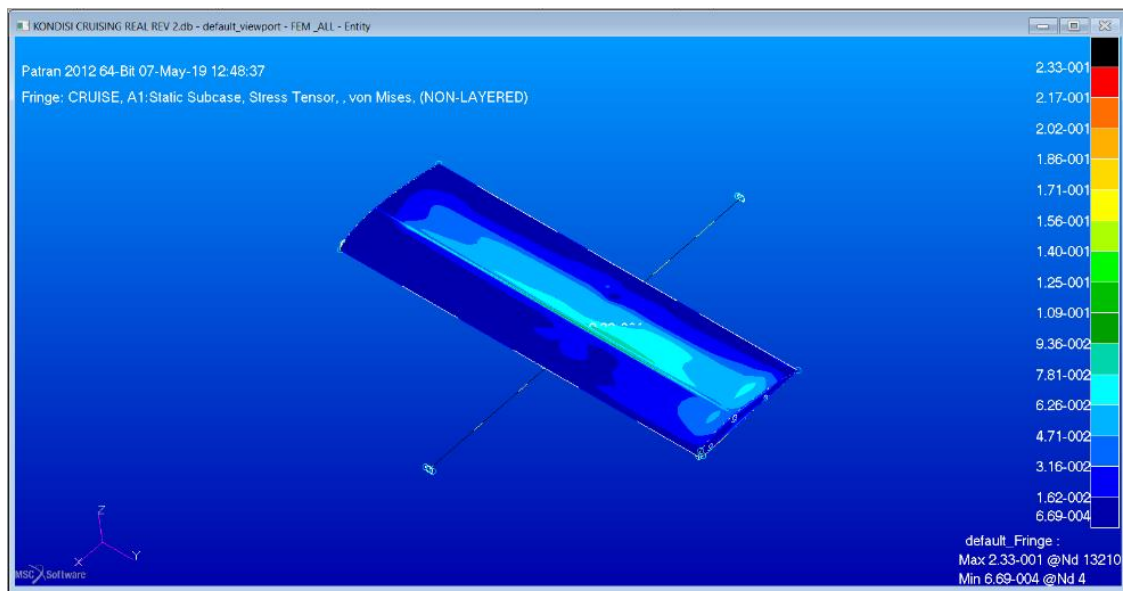

Gambar 5. Stress Tensor pada Core Sayap (Manuver)

Besar displacement maksimum adalah 26,5 mm pada node 5 terletak pada bagian tip sayap (Gambar 6), hal ini terjadi karena bagian tip adalah bagian yang bebas tidak ditumpu sehingga terjadi beban yang besar.

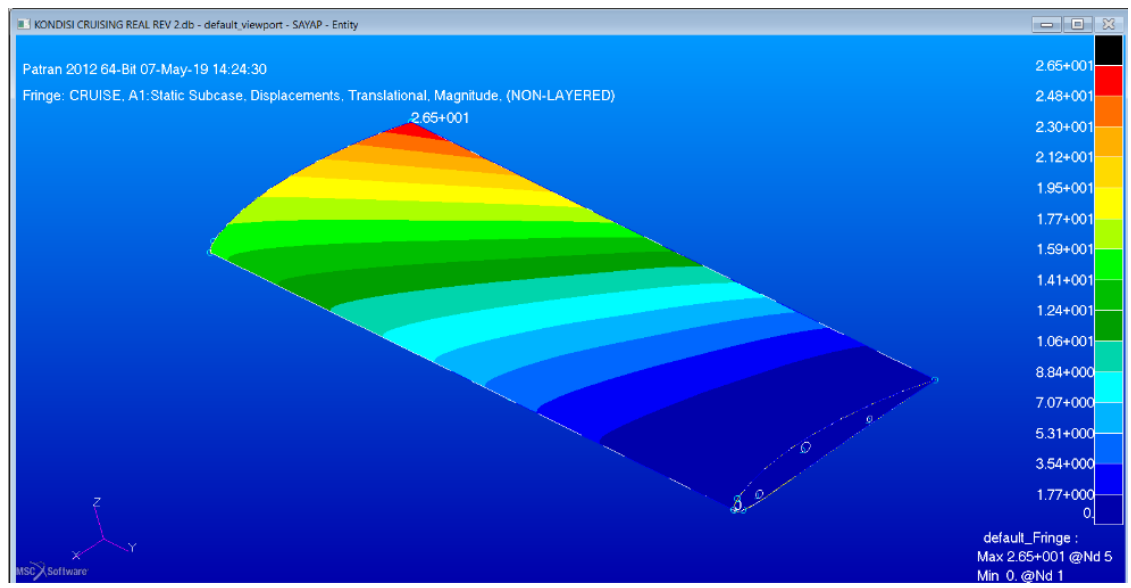

Gambar 6. Displacement pada Core Sayap (Manuver)

Besarnya nilai Perhitungan Margin of Safety yang terjadi pada core sayap adalah sebagai berikut: MS = $\frac{0,641 \mathrm{MPa}}{0,233 \mathrm{MPa}}-1=1,751$ 
Tabel 11. Nilai tegangan maksimum dan $M S$ pada kondisi beban manuver

\begin{tabular}{lccc}
\hline \multicolumn{1}{c}{ Part } & $\begin{array}{c}\text { Tegangan } \\
\text { Maksimum (MPa) }\end{array}$ & $\begin{array}{c}\text { Yield Strength } \\
(\mathrm{MPa})\end{array}$ & Margin of Safety \\
\hline Core Sayap & 0,233 & 0,641 & 1,751 \\
Stringer & 106 & 867 & 7,179 \\
Batang VTOL & 6,45 & 867 & 133,419 \\
\hline
\end{tabular}

3.2. Analisis struktur sayap pada beban torsi

Beban torsi sebesar 8.278,163 Nmm dikenakan pada ujung bagian engine mounting belakang. Tegangan maksimum sebesar 0,359 MPa terjadi pada node 8422 (Gambar 7). Letak maksimum tegangan ada pada bagian dekat root core sayap UAV. Hal ini terjadi karena clamp diletakkan pada sambungan sayap, sehingga momen maksimum terjadi pada root core sayap, sehingga tegangan maksimum terjadi di sekitar root core.

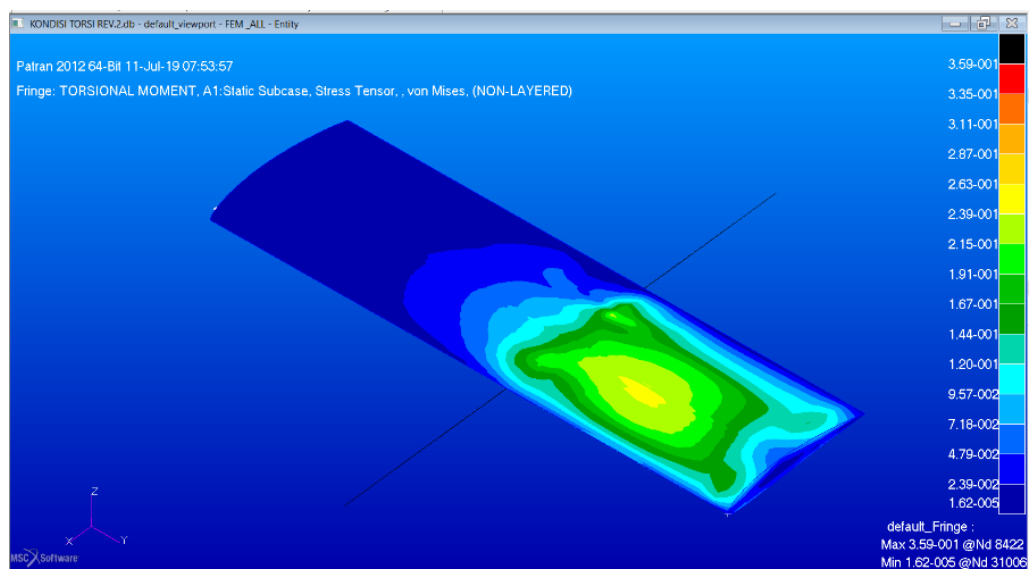

Gambar 7. Stress Tensor pada Core Sayap (Torsi)

Nilai displacement maksimum sebesar 30,7 mm pada node 5 (Gambar 8). Posisi tersebut terletak pada tip core sayap bagian belakang. Hal ini terjadi karena momen yang diaplikasikan pada rear engine mounting akan menyebabkan defleksi yang besar pada bagian bebas yang tidak ditumpu, bagian ini terletak pada tip.

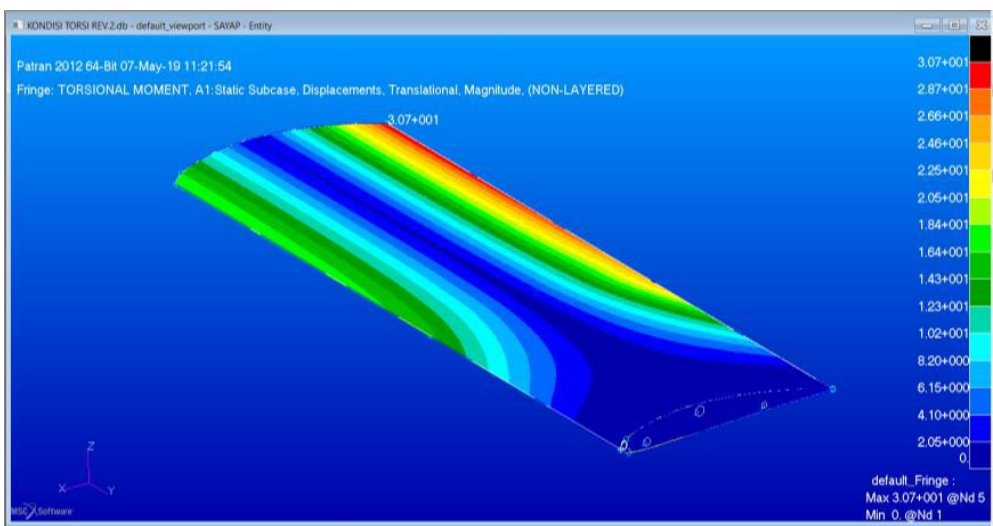

Gambar 8. Displacement pada Core Sayap (Torsi)

Pada stringer terjadi tegangan maksimum sebesar 185 MPa pada node 2015 posisinya di bagian stringer bagian belakang yang berdekatan dengan root core (Gambar 9). Beban momen bending akan diteruskan ke bagian core dan stringer, beban ini mengakibatkan permukaan core bawah mengalami beban tarik sedangkan bagian atas mengalami beban tekan. Hal ini menyebabkan stringer bagian belakang mengalami tegangan (tarik) lebih besar dibandingkan stringer bagian tengah yang mengalami tegangan tekan. 


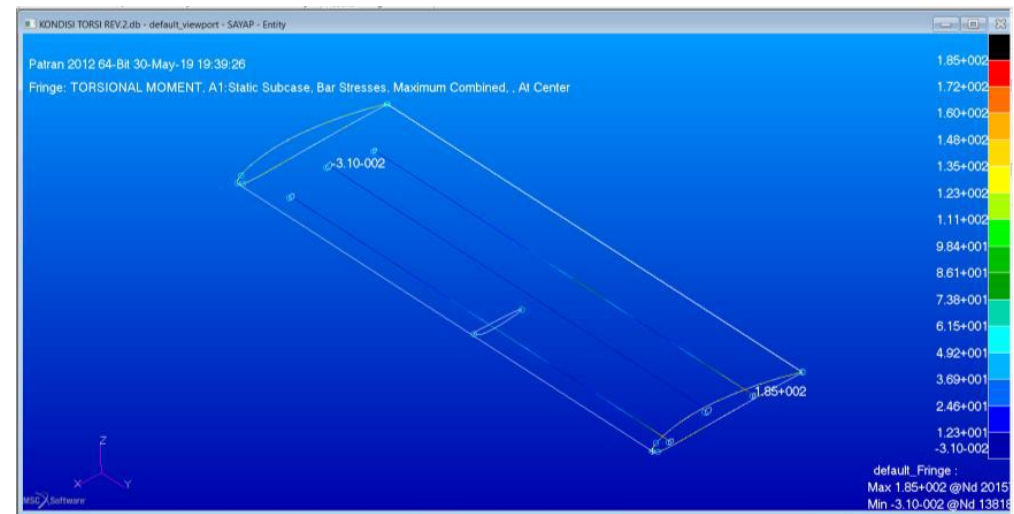

Gambar 9. Maximum Bar Stresses pada Stringer Sayap (Torsi)

Besarnya nilai Perhitungan Margin of Safety yang terjadi pada kasus ini bisa dilihat pada Tabel 12 berikut.

Tabel 12. Nilai tegangan maksimum dan $M S$ pada kondisi beban Torsi

\begin{tabular}{lccc}
\hline \multicolumn{1}{c}{ Part } & $\begin{array}{c}\text { Tegangan } \\
\text { Maksimum (MPa) }\end{array}$ & $\begin{array}{c}\text { Yield Strength } \\
(\mathrm{MPa})\end{array}$ & Margin of Safety \\
\hline Core Sayap & 0,359 & 0,641 & 0,785 \\
Stringer & 185 & 867 & 3,686 \\
Batang VTOL & 49,7 & 867 & 16,445 \\
\hline
\end{tabular}

3.3. Analisis struktur beban maneuver pada fuselage

Beban maneuver sebesar 106,82 $\mathrm{N}$ diberikan pada seluruh bagian fuselage dengan arah ke bawah, sedangkan posisi tumpuan diletakkan pada sambungan fuselage dengan core sayap. Tegangan maksimum 0,387 MPa terjadi pada node 672 (Gambar 10) bagian fuselage tepatnya posisi sambungan fuselage dengan core sayap, hal ini karena beban yang menimbulkan momen terbesar juga terjadi pada sambungan tersebut sehingga tegangannya akan sebanding dengan bebannya.

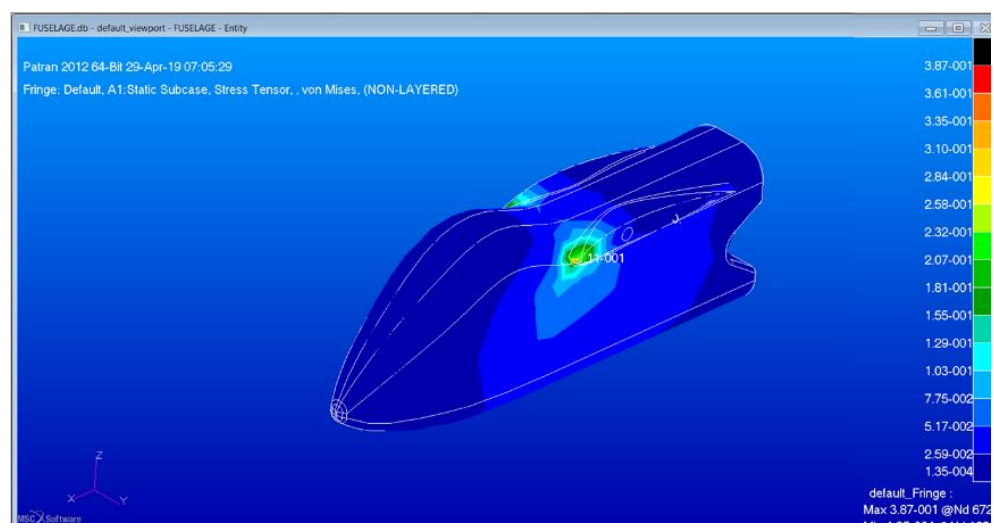

Gambar 10. Stress Tensor pada Fuselage

Sedangkan displacement maksimum 1,26 mm terjadi pada node 5737 (Gambar 11) di bagian ujung nose fuselage, hal ini karena bagian bebas yang ringan akan mudah terdefleksi dibandingkan bagian bebas yang lebih berat.

Besarnya nilai Margin of Safety yang terjadi fuselage adalah sebagai berikut.

$$
\mathrm{MS}=\frac{0,641 \mathrm{MPa}}{0,387 \mathrm{MPa}}-1=0,656
$$




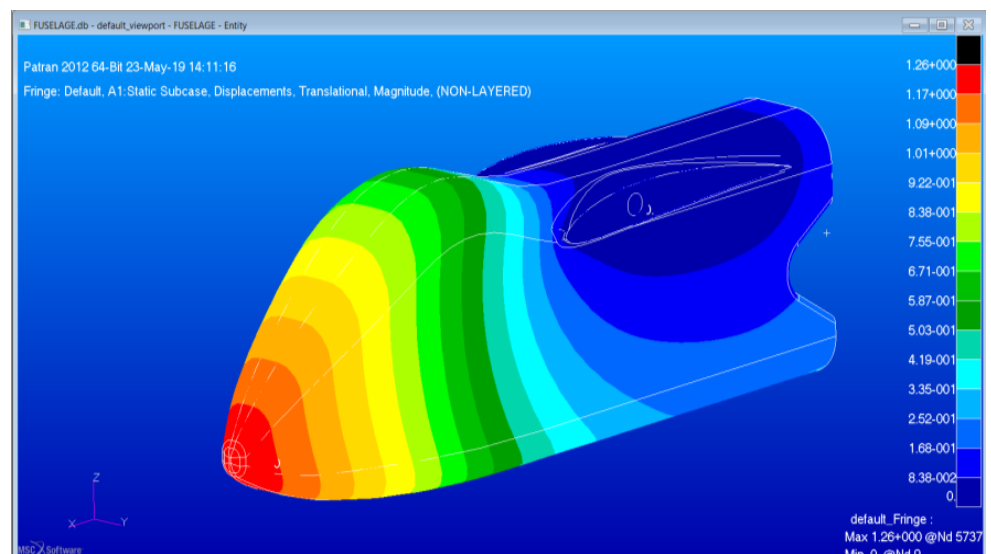

Gambar 11. Displacement pada Fuselage

3.4 Analisis struktur beban aerodinamik pada Tail

Tegangan pada tail terjadi pada dua part yaitu horizontal stabilizer dan vertical stabilizer.

1. Horizontal Stabilizer

Pada analisis horizontal stabilizer ada dua kasus pembebanan yaitu pull down $15^{0}$ dan pull up $15^{0}$. Hal ini dilakukan untuk melihat pengaruh dua kondisi tersebut terhadap letak stringer pada besar tegangan yang terjadi. Posisi stringer terletak di permukaan atas core.

Pada beban pull down $15^{0}$ (arah beban ke sumbu negatif Z) tegangan maksimum terjadi pada core horizontal stabilizer sebesar $0,464 \mathrm{MPa}$ pada bagian dekat root core, hal ini terjadi seperti kasus pembebanan maneuver pada bagian sayap. Sedangkan stringer mengalami tegangan sebesar $231 \mathrm{MPa}$, pada kasus ini stringer (posisi di upper surface)mengalami tegangan tarik.

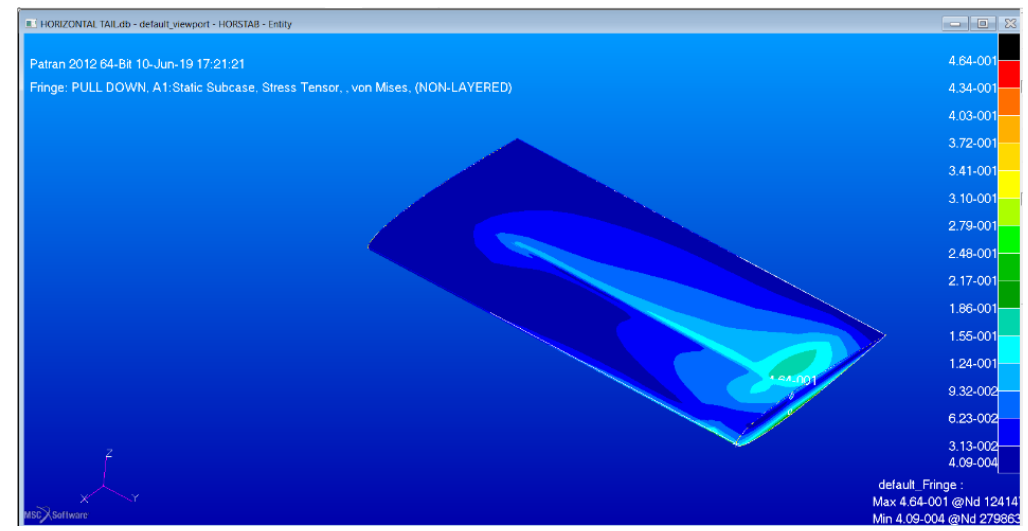

Gambar 12. Stress Tensor pada core horizontal stabilizer (Pull Down $15^{0}$ )

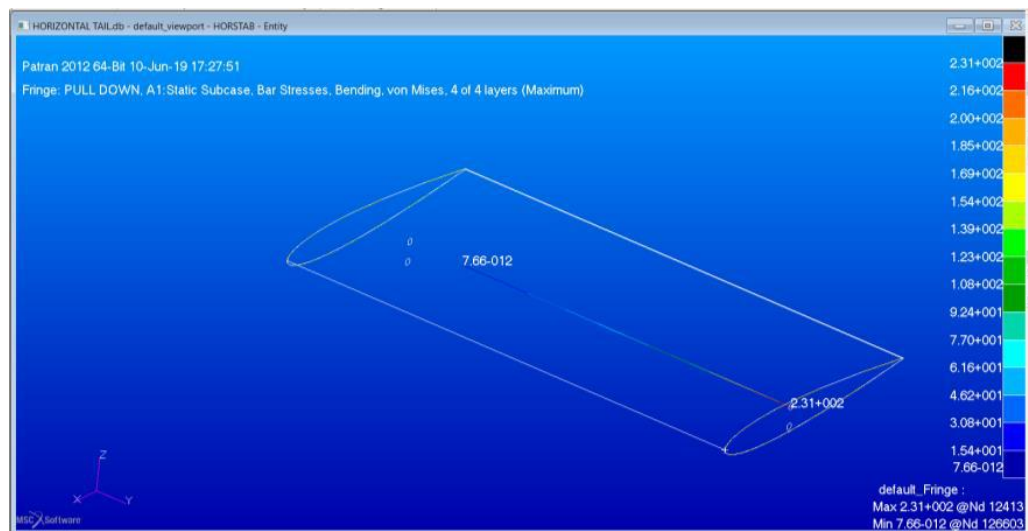

Gambar 13. Maximum Stresses pada stringer horizontalsStabilizer (Pull Down $15^{0}$ ) 
Sedangkan pada kasus pull up bagian yang mengalami tegangan tarik adalah tetap bagian permukaan core bawah, sehingga tegangan yang terjadi pada stringer adalah tegangan tekan $257 \mathrm{MPa}$. Apabila kita bandingkan dengan beban pull down, tegangan ini lebih besar hal ini terjadi karena akibat defleksi elevator $15^{\circ}$, ada beban tambahan ke bawah sehingga total besar yang diterapkan menjadi lebih besar sehingga tegangan tarik yang terjadi pada stringer menjadi lebih besar (Gambar 14).

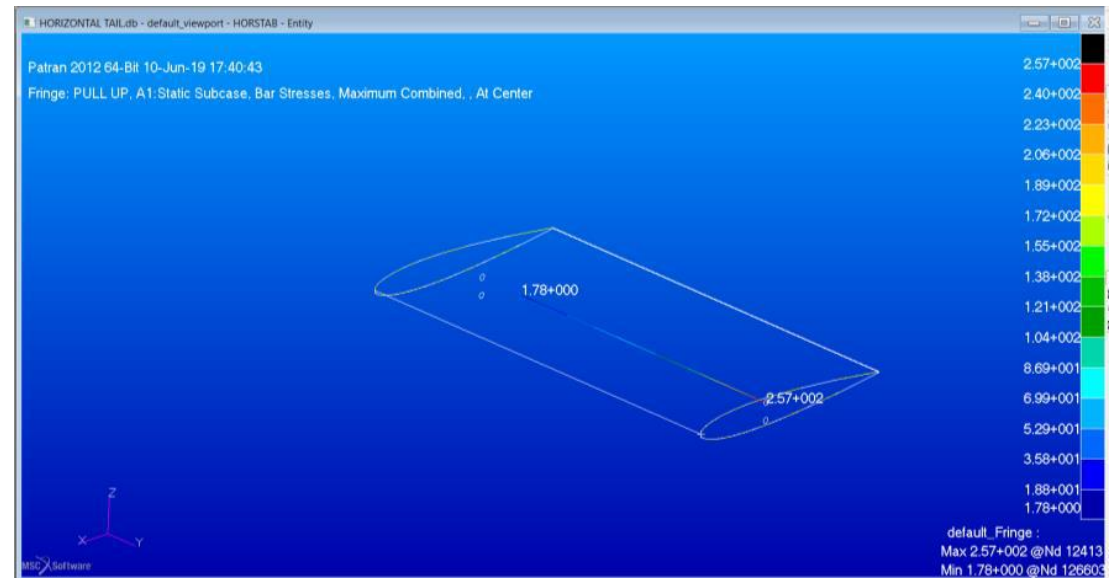

Gambar 14. Maximum bar stress pada stringer horizontal stabilizer (Pull Up $15^{0}$ )

\section{Vertical Stabilizer}

Pada pembebanan kondisi yawing $15^{\circ}$ tegangan maksimum pada core vertical stabilizer sebesar 0,246 MPa dengan posisi berada pada bagian root vertical stabilizer. Hal ini terjadi gaya yawing akan menyebabkan momen yang besar pada bagian root karena posisi clamp pemodelan ada di bagian ini, sehingga tegangan terbesar terjadi pada bagian root.

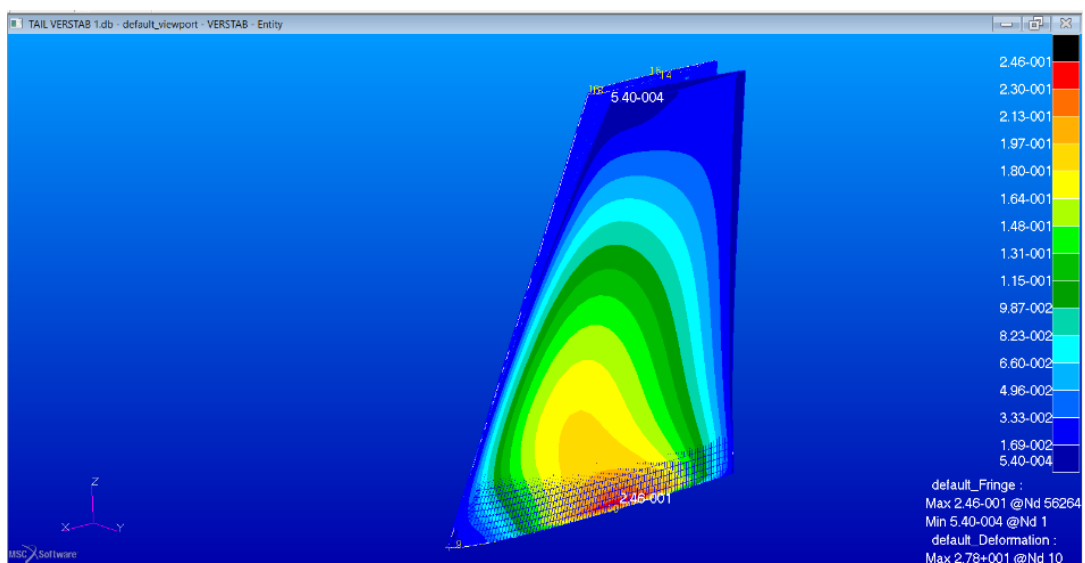

Gambar 15. Stress tensor pada core vertical stabilizer (Defleksi Yaw $15^{0}$ )

Berikut perhitungan nilai $M S$ yang dilakukan pada struktur tail.

Tabel 13. Nilai tegangan maksimum dan $M S$ pada kondisi beban

\begin{tabular}{lccc}
\hline \multicolumn{1}{c}{ Part } & $\begin{array}{c}\text { Tegangan } \\
\text { Maksimum (MPa) }\end{array}$ & $\begin{array}{c}\text { Yield Strength } \\
(\mathrm{MPa})\end{array}$ & Margin of Safety \\
\hline $\begin{array}{l}\text { Core Horizontal } \\
\text { (Pull down) }\end{array}$ & 0,464 & 0,641 & 0,381 \\
$\begin{array}{l}\text { Stringer Horizontal } \\
\text { (Pull down) }\end{array}$ & 231 & 867 & 2,753 \\
$\begin{array}{l}\text { Core Horizontal (Pull up) } \\
\text { Stringer Horizontal }\end{array}$ & 0,466 & 0,641 & 0,376 \\
& 257 & 867 & 2,374
\end{tabular}


(Pull up)

$\begin{array}{lll}\text { Core Vertical Stabilizer } & 0,246 & 0,641\end{array}$

(Kondisi Yaw)

\section{Kesimpulan}

Dari hasil analisis struktur yang telah dilakukan pada struktur sayap, fuselage dan tail pesawat UAV VTOL VX-2 dapat disimpulkan sebagai berikut:

1. Perubahan pada sayap meliputi peletakan posisi stringer yang lebih tepat, metode sambungan antar part menggunakan sistem lepas pasang (modular), menambah jumlah stringer menjadi tiga buah untuk menjaga kekakuan dan kekuatan sayap agar tidak terjadi over deflection.

Perubahan fuselage meliputi penambahan ukuran dimensi baik eksternal maupun internal, maupun memperbaiki bentuk permukaan untuk mengurangi timbulnya gaya hambat, serta membuat mounting untuk metode assembly part lepas pasang (modular).

Pada bagian tail, perubahan yang dilakukan adalah memperbaiki sambungan antara part horstab dan verstab, mengurangi jumlah stringer menjadi satu buah pada horizontal tail.

2. Pada struktur sayap tegangan terbesar terjadi pada kasus beban torsi terletak di stringer sebesar 185 MPa. Struktur fuselage tegangan terbesar terjadi pada kasus pembebanan maneuver pull up letaknya di root sambungan sayap sebesar $0,387 \mathrm{MPa}$. Sedangkan pada struktur tail tegangan terbesar pada kasus pull up yaitu terletak di stringer horizontal stabilizer sebesar $257 \mathrm{MPa}$.

3. Berdasarkan nilai keseluruhan margin of safety struktur pesawat UAV VTOL VX-2 dinyatakan aman karena semua nilainya positif.

\section{Ucapan Terimakasih}

Atas terlaksananya penelitian ini penulis mengucapkan terima kasih kepada Sekolah Tinggi Teknologi Adisutjipto yang telah memberikan dukungan finansial serta fasilitasnya.

\section{Daftar Pustaka}

[1] Junarto, R., Djurdjani, Permadi, F. B., Ferdiansyah, D., Admaja,P. K., Sholikin, A. R., Rahmansani, R., (2020). Pemanfaatan Teknologi Unmanned Aerial Vehicle (UAV) Untuk Pemetaan Kadaster, Bhumi, Jurnal Agraria dan Pertanahan, Vol. 6, No. 1, 105-118.

[2] Gadiya, P., Patheria, A., Chib, K., Gore, A., (2017). Design, Analysis and Fabrication of QuadCopter for Emergency Medical Services using GPS, International Journal Of Research In Mechanical Engineering and Technology (IJRMET), Vol. 7, Issue 2.

[3] Yayli, U.C., Kimet, C., Duru, A., Cetir, O., Torun, U., Aydogan, A.C., Padmanaban, S., Erta, A.H., (2017). Design Optimization of A Fixed Wing Aircraft, Advances in Aircraft and Spacecraft Science, Vol. 4, No.1 65-80.

[4] Patra, A. K., Patel, K., Bundela, G. S., Vinay., (2017). Design and Development of Transition Autopilot for VTOL UAV, International Journal Of Innovations In Engineering Research and Technology (IJIERT), Vol. 4, Issue 6.

[5] Sandilya, B. V., Kumar K. S., Kumar P. S., Shyam Y. S., (2014). Design And 3D Modelling Of Vertical Take Off And Landing (VTOL) Tilt Quad Rotor RC Aircraft, Proceedings of 5th SARC-IRF International Conference, Bangalore, India

[6] Agarwal, S., Mohan, A., Kumar, K., (2014), Design, Construction And Structure Analysis Of Twinrotor UAV, International Journal of Instrumentation and Control Systems (IJICS), Vol.4, No.1.

[7] Dundar, O., Bilici, M., Unler, T., (2020), Design and Performance Analyses of a Fixed Wing Battery VTOL UAV, International Journal of Engineering Science and Technology, 23,1182-1193.

[8] Saengphet, W., Thumthae, C., (2016), Conceptual Design of Fixed Wing-VTOL UAV for AED Transport, The 7th TSME International Conference on Mechanical Engineering.

[9] Ozdemir, U., Aktas, Y. O., Vuruskan, A., Dereli, Y., Tarhan, A.F., Demirbag, K., Erdem, A., Kalaycioglu, G. D., Ozkol, I., Inalhan, G., (2014) Design of a Commercial Hybrid VTOL UAV System, Journal of Intelligent and Robotic Systems, 74:371-393.

[10] Santoso, D. W., Putra A. N., (2018). Design And Analysis The Strength Of The Structure Fixed Wing Vertical Take Off Landing UAV, Prosiding SENATIK STTA, Vol. IV, pp 3-12. 
[11] Niu, Michael C.Y, (2001). Airframe Stress Analysis and Sizing, Conmilit Press Ltd., Hongkong.

[12] Civil Aviation Safety Authority Australia, (2000). Design Standards: Unmanned Aerial Vehicles Aeroplanes.

[13] Nirmalasari. D. P, (2019), Analisis Kekuatan Struktur Tail Pada Pesawat UAV V-SKY 14 Menggunakan Software ANSYS, Sekolah Tinggi Teknologi Adisutjipto, Yogyakarta.

[14] http://www.matweb.com/search/DataSheet.aspx?MatGUID=39e40851fc164b6c9bda29d798bf3726 \&ckck=1) 